\title{
Hemocyte functions and bacterial clearance affected in vivo by TBT and DBT in the blue mussel Mytilus edulis
}

\author{
S. D. St-Jean ${ }^{1,2}$, É. Pelletier ${ }^{2, *}$, S. C. Courtenay ${ }^{1}$ \\ ${ }^{1}$ Fisheries and Oceans Canada, Gulf Fisheries Centre, PO Box 5030, Moncton, New Brunswick E1C 9B6, Canada \\ ${ }^{2}$ Institut des sciences de la mer à Rimouski (ISMER), Université du Québec à Rimouski, 310 allée des Ursulines, Rimouski, \\ Québec G5L 3A1, Canada
}

\begin{abstract}
The effects of tributyltin (TBT) and dibutyltin (DBT) on the hemocyte functions of the blue mussel Mytilus edulis were investigated in 2 separate experiments at 2 different cold periods of the year. In Expt 1, we exposed mature mussels to waterborne TBT or DBT (from 5 to $80 \mathrm{ng} \mathrm{Sn} \mathrm{l}^{-1}$ ) under flow-through conditions. The mussel hemocytes were monitored for membrane injury (MI), phagocytic activity (PA), lysosome retention (LR) and hemocyte count (HC) over $32 \mathrm{~d}$. Both TBT and DBT significantly affected all cellular functions measured. MI was present as early as Day 1 for TBT doses $>10 \mathrm{ng} \mathrm{Sn}^{-1}$ and DBT $>20 \mathrm{ng} \mathrm{Sn}^{-1}$ in Expt 1, and by Day 32 all doses of TBT and all DBT doses $>5 \mathrm{ng} \mathrm{Sn}^{-1}$ had produced significant MI increases. PA was reduced by all doses of TBT and DBT in

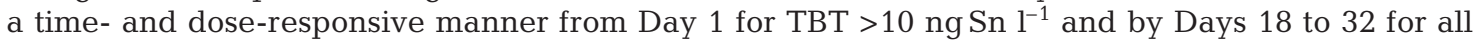
doses of both chemicals. LR was significantly elevated by DBT dose of $80 \mathrm{ng} \mathrm{Sn} \mathrm{l}^{-1}$ between Days 1 and 4 but not thereafter. Significant elevations and depressions in HC were observed in mussels exposed to both butyltins, although effects were highly variable and not clearly related to either dose or time of exposure. To confirm our first observations, Expt 2 was carried out using mussels exposed to 40 and $80 \mathrm{ng} \mathrm{Sn}^{-1}$ TBT or DBT over $13 \mathrm{~d}$ under the same experimental design. The hemocytes were monitored for: (1) PA using both microscopic and spectrophotometric observations; (2) LR using 2 incubation times; and (3) HC in hemolymph from individual and pooled mussel samples. The general trends of Expt 1 results were confirmed. In addition to hemocyte assays, mature mussels from Expt 1 as well as mature and juvenile mussels from Expt 2 were injected with the common bacterium Listonella (= Vibrio) anguillarum after 32 and $13 \mathrm{~d}$ of exposure, respectively, to TBT or DBT concentrations described above. For both butyltins, a significant dose-related impairment in clearing Vibrio from the hemolymph was observed for all doses in both experiments. Clearance of bacteria was slower for the juveniles than for the adults suggesting that the early life stages of mussels may be more affected by butyltin exposure than adults. This study established strong and sustained responses of hemocyte functions of blue mussels exposed to environmentally relevant, waterborne concentrations of TBT and DBT (0.04 to $0.67 \mathrm{nM}$ as Sn) which is interpreted as an increase of their vulnerability to other environmental stressors and pathogens, even at low seawater temperatures, $\left(<5^{\circ} \mathrm{C}\right)$ often present in high latitude coastal waters.
\end{abstract}

KEY WORDS: Blue mussels $\cdot$ Butyltins $\cdot$ TBT $\cdot$ DBT $\cdot$ Hemocytes $\cdot$ Membrane injury $\cdot$ Bacterial clearance $\cdot$ Phagocytosis $\cdot$ Lysosome retention $\cdot$ Bioaccumulation

Resale or republication not permitted without written consent of the publisher

\section{INTRODUCTION}

Internal defense in bivalves relies largely on circulating hemocytes and a wide range of nonimmuno- globulin serum proteins to identify and eliminate potential pathogens. Hemocytes are often the primary targets of many contaminants, which has serious consequences for their homeostasic capacity (Auffret \& 
Oubella 1997). As a consequence, any toxicant that interferes with hemocyte functions may increase vulnerability of targeted organisms to other environmental stressors and ultimately expression of disease. Therefore, the study of the physiology and defense mechanism of this system is crucial in assessing the toxicity associated with xenobiotics in the coastal environment, where bivalves often constitute a major contribution to the local and national economy.

Tributyltin (TBT) is still used worldwide as an antifoulant in marine paints and is accumulated within the tissues of biota (Fent 1996). Despite a partial ban imposed on boats $<25 \mathrm{~m}$ in most industrialized countries during the 1980s, hotspots still remain in areas of intense shipping activity (Waite et al. 1991). TBT concentrations up to $133 \mathrm{ng} \mathrm{Sn} \mathrm{l}^{-1}$ were reported for Danish coastal waters (Kure \& Depledge 1994), between 14 and $28 \mathrm{ng} \mathrm{Sn}^{-1}$ in Alexandria Harbor (Abd-Allah 1995) and up to $105 \mathrm{ng} \mathrm{Sn}^{-1}$ in wastewater from Zurich, Switzerland (Fent \& Hunn 1995). Some French coastal locations still showed TBT levels of $>36 \mathrm{ng} \mathrm{Sn}^{-1}$ in 1997 (Michel \& Averty 1999). Concentrations of butyltins in the order of $\mathrm{ng} \mathrm{l}^{-1}$ are known to cause deleterious effects to marine biota. Best-documented examples include: mussel larval mortality (Beaumont \& Budd 1984); shell abnormalities in the oyster Crassostrea gigas (Alzieu et al. 1981); imposex in neogastropod molluscs (Bryan et al. 1987); and disruption of oxidative phosphorylation in all animals tested (Fent 1996).

Only a few studies have related immunomodulations in bivalves to TBT exposure. Chemiluminescence (an indirect indicator of phagocytosis), locomotion of hemocytes and time to spread were shown to be modulated by in vitro exposure to TBT (Fisher et al. 1990). Furthermore, Fisher et al. (1995) showed the virulence of the protozoan pathogen Perkinsus marinus in the oyster Crassostrea virginica to be correlated to TBT exposure. Anderson et al. (1996) also reported similar results. In addition, hemocyte aggregation, which is associated with the internal defense of bivalves, was disrupted in C. gigas (Auffret \& Oubella 1997) as well as Mytilus edulis (Oubella, 1997) following in vitro exposure to TBT. Although these and other studies have provided important information, the relationships between in vivo exposure to butyltins and immunocompetence or immune functions over time in bivalves have not yet been described.

Beyond exploring the impacts of the butyltins TBT and DBT on hemocyte functions and comparing their relative toxicities to blue mussels, we were interested in the field relevance of these changes and in determining whether butyltin-induced alterations of hemocyte functions translate into a reduced ability to clear bacteria from the hemolymph. Various marine Vibrio spp. are known to be a threat to mollusk husbandry (Elston
1984). Jeffries (1983) reported that pathogenic Vibrio could cause up to $90 \%$ mortalities of oyster larvae within $24 \mathrm{~h}$. It is generally accepted that infection of adult bivalves by bacteria, including Vibrio, in the natural environment is rare (Nottage \& Birkbeck 1990, Lambert \& Nicholas 1998). However, McHenery \& Birkbeck (1986) reported that 8 Vibrio species rapidly inhibited filtration by adult Mytilus edulis while Escherichia coli and Pseudomonas and 7 other bacterial species were readily ingested by the mussels. More recently, it was shown that a range of Vibrio strains induced an inhibition of chemiluminescence, associated with the respiratory burst utilized in bacterial degradation, in adult mussel hemocytes (Lambert \& Nicholas 1998). Finally, Lane \& Birkbeck (1999) reported that very small numbers of Vibrio induced cell rounding, thus preventing movement, in adult mussel hemocytes that had previously been allowed to attach to the plastic surface of a tissue culture plate. Although Vibrio spp. are not recognized as a pathogen of the adult mussel, we selected Listonella (= Vibrio) anguillarum as a model invader for our bacterial challenge.

The 3 main objectives of this study were: (1) to describe changes in hemocyte functions in blue mussels exposed continuously to various doses of waterborne TBT and DBT over 2 and 4 wk periods; (2) to compare the relative toxicity of TBT and $\mathrm{DBT}_{\text {; }}$ and, (3) to describe the relationships between altered hemocyte functions of mussels exposed to TBT and DBT and their ability to clear bacteria from their hemolymph. To achieve these objectives while permitting repeated sampling of the same individuals over an extended period of time, end-points measured were: hemocyte count (HC), phagocytic activity (PA), lysosome retention (LR), membrane injury (MI) and clearance of bacteria. A first experiment was carried out for a $32 \mathrm{~d}$ period with doses of TBT and DBT ranging from 5 to $80 \mathrm{ng} \mathrm{Sn}$ $\mathrm{I}^{-1}$. To confirm the observed results, and also to examine possible bias introduced by analytical techniques used in Expt 1, Expt 2 was carried out in which mussels

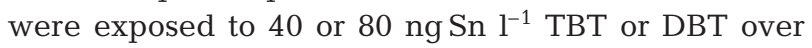
$13 \mathrm{~d}$. Specifically, we examined: (1) the effects of pooling hemolymph from different mussels on $\mathrm{HC}$ and $\mathrm{MI}_{\text {; }}$ (2) the difference between spectrophotometric and microscopic techniques on $\mathrm{PA}_{i}(3)$ the influence of incubation time on LR; and (4) the responses of adult and juvenile mussels to the bacterial inoculation. Chemical analyses were carried out at the end of both experiments to quantify bioaccumulation of butyltin species.

\section{MATERIALS AND METHODS}

All chemicals were certified grade for the dyes or pesticide grade for the solvents and were purchased 
from Sigma Chemical. A stock solution of Tris-buffered saline (TBS), $\mathrm{pH}$ 8.4, was used as the dilution medium for the dyes, and consisted of $17.3 \mathrm{ml}$ of $0.1 \mathrm{~N} \mathrm{HCl}$ made up to $100 \mathrm{ml}$ with distilled water added to $25 \mathrm{ml}$ of $0.2 \mathrm{M}$ aqueous Trizma base. $\mathrm{NaCl}(2.5 \% \mathrm{w} / \mathrm{v})$ was added to maintain osmolarity between 1000 and 1200 mOsm (Grundy et al. 1996). The TBS solution was filtered $(0.2 \mu \mathrm{m})$ before each sampling day.

Expt 1. Mussels: Mature blue mussels Mytilus edulis between 6.5 and $8.5 \mathrm{~cm}$ in shell length were obtained in March 1998 from a local fisherman at Grande Digue Bay (southern Gulf of St. Lawrence, NB) and immediately transported under optimum conditions to the laboratory facilities in Rimouski, Qc. Mussels were then cleaned of all epibionts and allowed to acclimatize at 4 to $5^{\circ} \mathrm{C}$ in a flow-through aquarium for $2 \mathrm{wk}$. Two $\mathrm{d}$ prior to the beginning of the exposure, the mussels were divided among 11 flow-through aquaria (7.5 l) supplied with non-filtered seawater pumped from St. Lawrence Estuary (mean salinity 28) and flow rate was established at $13 \mathrm{l} \mathrm{h}^{-1}$ ensuring a rapid renewal of water in each aquarium. Thirty mussels were placed in each aquarium, 5 groups of 4 animals were randomly selected and put into separate mesh bags (labeled for subsequent identification). The other 10 mussels remained untouched for the duration of the experiment and were used only for the bacterial challenge.

Exposure: Stock solutions of $2.68 \mu \mathrm{g} \mathrm{Sn} \mathrm{l}^{-1}$ in ethanol were prepared for each butyltin species and from these stock solutions, distribution of contaminants to each aquarium was made with peristaltic pumps to obtain final concentrations of 5, 10, 20, 40 and $80 \mathrm{ng} \mathrm{Sn} \mathrm{l}^{-1}$ for TBT and DBT corresponding to molar concentrations of $0.04,0.08,0.16,0.33$ to $0.67 \mathrm{nM}$ as $\mathrm{Sn}$. To minimize adsorption of the butyltins on tubing and aquarium walls and maximize bioavailability to mussels, dried Spiruline (Sigma) was added to the stock solution in a 10:1 ratio (ng of algae:ng of butyltin). This addition contributed very little to feed the mussels and seawater pumped from the St. Lawrence Estuary contained no phytoplankton cells during the course of this experiment, which is considered normal for that winter period of the year. Mussels were sampled on Days 0,1 , $4,11,18,25$ and 32 .

Hemolymph extraction: Preliminary sampling indicated that an average of $2.5 \mathrm{ml}$ of hemolymph per mussel could be extracted in total. Therefore, to minimize experimental stress, no more than $0.5 \mathrm{ml}$ was extracted from each mussel at each sampling. The mussel valves were gently pried open around the byssus, any mantle fluid was drained, a sterile 20 gauge needle was inserted directly in the posterior adductor muscle sinus and $0.5 \mathrm{ml}$ hemolymph was extracted into a dry $3 \mathrm{ml}$ syringe and divided into 4 subsamples: $0.1 \mathrm{ml}$ for the MI assay, $0.1 \mathrm{ml}$ (fixed immediately with Baker's for- mol) for the hemocyte counting with a hemocytometer, $0.1 \mathrm{ml}$ for the LR assay and $0.2 \mathrm{ml}$ for the phagocytosis assay. The operation was repeated for the 4 mussels contained in each bag and hemolymph was then pooled for a total of 5 pools of 4 individuals each per aquarium and each sampling day.

Lysosome retention (LR): LR was evaluated by using neutral red dye following the technique described by Lowe \& Pipe (1994). Aliquots of $100 \mu \mathrm{l}$ pooled hemolymph were added to $200 \mu \mathrm{l} 2 \%$ neutral red dye in TBS, in a sterile centrifuge tube, and incubated at room temperature for $5 \mathrm{~h}$. The cells were then washed with TBS, fixed $2 \%$ glutaraldehyde in TBS, and centrifuged at $800 \times g$ for $10 \mathrm{~min}$. The fixative solution was then removed with a Pasteur pipette, $1 \mathrm{ml}$ of TBS was added and the preparation was stored cold in the dark. Prior to the readings, TBS was removed and $1 \mathrm{ml}$ extraction solution consisting of $1 \%(\mathrm{v} / \mathrm{v})$ acetic acid plus $50 \%$ $(\mathrm{v} / \mathrm{v})$ ethanol in distilled water was added for $30 \mathrm{~min}$ (Grundy et al. 1996). Neutral red retained by the hemocytes was displaced by the addition of the extraction solution and measured at $540 \mathrm{~nm}$ on a PerkinElmer spectrophotometer, calibrated with the extraction solution. Data reported are optical densities and were standardized to $10^{6}$ cells.

Membrane injury (MI): Quantification of MI to hemocytes was carried out with a nigrosine dye test. The dark blue dye enhances the contrast of the outer cell membrane and enables detection of abnormal cell shape. Pooled hemolymph $(100 \mu \mathrm{l})$ was placed in a clean well, overlaid with an equal volume of $0.2 \%$ nigrosine in TBS and incubated at room temperature for 1 to $5 \mathrm{~min}$. The percentage of damaged cells was calculated from 150 cells examined under a phase contrast microscope at $40 \times$ magnification.

Phagocytic activity (PA) and hemocyte count (HC): The fluorescent dye, fluorescein-isothiocyanate (FITC) suspended in TBS solution, was added to the yeast zymosan type 1 in excess, and incubated for $2 \mathrm{~h}$ at room temperature with periodic mixing. The labeled yeast were then washed repeatedly with TBS until the supernatant contained no yellow fluorescence. Subsamples of $1 \mathrm{ml}$ were then frozen at $-20^{\circ} \mathrm{C}$ until used. Densities of the labeled yeast were ascertained in all samples with a fluorescence microscope and ranged from 4 to $5 \times 10^{7} \mathrm{ml}^{-1}$.

Hemocyte numbers in $0.4 \mathrm{ml}$ hemolymph, pooled from mussels at $0.1 \mathrm{ml}$ each and adjusted to $1 \mathrm{ml}$, were determined using an Improved Neubauer hematocytometer. Fluorescent yeast were then added to the hemocyte solution in a 100:1 density ratio and left to incubate at room temperature in the dark for $5 \mathrm{~h}$, after which they were evaluated for PA. To prevent dehydration of samples, $0.5 \mathrm{ml}$ of a $4 \%$ Bovine Serum Albumin (BSA) solution diluted in RPMI 1640 (Sigma) was 
added to each sample. To distinguish yeast that had been phagocytosed from yeast attached to the external cell membrane, $1 \mathrm{ml}$ of a $0.05 \%$ ethidium bromide (EB) solution was added to the sample just prior to microscope observation. The EB reacted quickly with the FITC of unphagocytized yeast, which lowered its wavelength from a bright green to a mat green; all other cells and debris were colored bright red. Fluorescent zymosans inside phagocytes were protected by the membrane and thus remained bright green. The activity of the first 300 hemocytes encountered was characterized as either active (phagocyte full of zymosans with little free space in cytoplasm) or inactive ( $<10 \%$ of cytoplasm contains zymosans). Results are expressed as a percentage of active cells. The presence of aggregated cells was also recorded.

Bacterial challenge: Preparation of stock bacteria: A pure strain of Listonella (= Vibrio) anguillarum was obtained from the University of Prince Edward Island (PEI, Canada) and maintained on marine agar. To ascertain that the bacteria counted after the challenge were $L$. anguillarum and not from the natural bacterial population, we progressively rendered the original strain resistant to 2 antibiotics: streptomycin and rifampicin, and then maintained the resistant strain on marine agar containing $500 \mathrm{mg} \mathrm{l}^{-1}$ of streptomycin and $100 \mathrm{mg} \mathrm{l}^{-1}$ rifampicin. Prior to inoculation of the mussels, an inoculum of $L$. anguillarum was transferred into an antibiotic-free solution of marine broth (Difco) and left to grow at room temperature for $24 \mathrm{~h}$, at which point the bacterial culture had reached the exponential growth phase.

Bacterial number estimation: The concentration of the bacteria $\left(10^{7} \mathrm{ml}^{-1}\right)$ at the exponential phase was established by using the most probable number (MPN) technique. This technique consists of preparing a decimal dilution series from a known volume of bacterial solution in a 96 multi-well sterile microplate. The wells were examined visually for the lowest concentration to contain bacteria. To prevent contamination of the wells, $250 \mathrm{mg} \mathrm{l}^{-1}$ of streptomycin, $100 \mathrm{mg} \mathrm{l}^{-1}$ rifampicin and $10 \mathrm{mg} \mathrm{l}^{-1}$ of cyclohexamide, a fungicide, were added. To verify that only Vibrio could grow in the wells, we intentionally contaminated several culture tubes containing the same antibiotic/fungicide concentration. No growth was noted in the test tubes after $7 \mathrm{~d}$ of incubation at room temperature.

Bacterial clearance experiment: Tests were carried out on 10 mussels in each aquarium that had been exposed to various doses of TBT or DBT for $32 \mathrm{~d}$ or not exposed (controls), but not manipulated in any previous assay. An optimal volume of $0.5 \mathrm{ml}$ bacterial suspension $\left(5 \times 10^{6}\right.$ bacteria) was injected in the visceral mass of each mussel. The mussels were then closed tightly with elastic bands to avoid any leaking and left out of the water at cool room temperature $\left(12^{\circ} \mathrm{C}\right)$ for $2 \mathrm{~h}$. The mussels were then freed and permitted to purge themselves in clean flow-through aquaria for $4 \mathrm{~d}$, before sampling commenced. The mussels were tested for bacterial clearance 4 and $14 \mathrm{~d}$ after the inoculation by drawing $0.5 \mathrm{ml}$ of hemolymph from each individual. From each sample, 3 aliquots of $20 \mu \mathrm{l}$ were used to assess the bacterial levels remaining in each mussel by using the MPN technique, and the mean of these samples was used for the statistical analysis.

Chemical analysis: At the end of the experiment, soft tissue from 20 mussels in each aquarium was blended and the homogenate was divided into 3 subsamples, which were analyzed separately. The results are reported as an average \pm 1 SD of 3 replicates for each sample. The techniques used to quantify butyltin concentrations have been developed previously by the same laboratory (St-Louis et al. 1997, St-Jean et al. 1999). A Finnigan MAT ion-trap detector (ITD) splitless coupled to a Perkin-Elmer Model 8500 gas chromatograph (GC) were used with a DB5 fused silica capillary column ( $30 \mathrm{~m} \times 0.25 \mathrm{~mm}$ in diameter). Butyltins were extracted from dry samples by hexane/ tropolone solution, ethylated with $\mathrm{NaBEt}_{4}$, purified on a silica gel column and quantified from a standard curve established with known concentrations of ethylated TBT and DBT.

Expt 2. Mussels: Mature blue mussels (100) between 6.5 and $8 \mathrm{~cm}$ in shell length and 50 juvenile blue mussels between 1 and $2 \mathrm{~cm}$ in shell length were obtained in December 1999 from the same location as the previous samples and acclimatized at 2 to $3^{\circ} \mathrm{C}$ in a flowthrough aquarium for $4 \mathrm{~d}$. One day prior to the beginning of the experiment, mature and juvenile mussels were divided equally among 5 aquaria $(7.5 \mathrm{l})$. The experimental design was identical to that previously described, with the addition of an ultraviolet sterilizer on the incoming water, intended to ensure that incoming bacteria would not be introduced to the system. In each aquarium, 10 mature mussels were randomly selected, separated from the others within a mesh bag and left untouched for the final bacterial clearance.

Hemolymph extraction was performed as previously described with the following modifications: $0.6 \mathrm{ml}$ hemolymph was extracted from each of the 10 remaining adult mussels with a sterile 23 gauge needle into a $3 \mathrm{ml}$ syringe containing $0.6 \mathrm{ml}$ of TBS. The hemolymph/TBS solution was then divided into 6 subsamples: $0.1 \mathrm{ml}$ for HC with pooled (2 mussels) hemolymph, $0.1 \mathrm{ml}$ for $\mathrm{HC}$ with non-pooled hemolymph, $0.1 \mathrm{ml}$ for PA using microscopic technique, $0.3 \mathrm{ml}$ for PA using spectrophotometric technique, $0.3 \mathrm{ml}$ for LR with $4 \mathrm{~h}$ incubation time and finally $0.3 \mathrm{ml}$ for LR with 30 min incubation time. Spectrophotometric analyses were made in triplicate and the mean of these results 
was used in the statistical analysis. Precision of each assay was expressed as the mean coefficient of variation for the 10 mussels and was $10.2 \%$ for PA with spectrophotometer and $6.4 \%$ with fluorescence, $13.1 \%$ for LR 30 min incubation and $12.6 \%$ for $4 \mathrm{~h}$ incubation, and finally $27.2 \%$ for $\mathrm{HC}$ of pooled cells and $19.5 \%$ for non-pooled samples. Results were expressed as a mean average.

Exposure was carried out as previously described, with the following modifications: only 2 nominal concentrations were used (40 and $80 \mathrm{ng} \mathrm{Sn} \mathrm{l}^{-1}$ for TBT or DBT) and no dried spiruline was added to the stock solution assuming adsorption was minimal after conditioning of tubes and glassware for $24 \mathrm{~h}$. As in Expt 1, mussels were not fed during the exposure period. Mussels for assays were sampled on Days 0, 1,6 and 13. Although MI was not quantified, cells were observed for the presence of any deformity.

Lysosome retention (LR): Three aliquots of $100 \mu \mathrm{l}$ hemolymph per mussel were added to $200 \mu$ l of $2 \%$ neutral red dye in TBS in microplate wells and left to incubate in the dark at room temperature for $4 \mathrm{~h}$. Cells were then washed by centrifugation with TBS $(100 \times g$ for $5 \mathrm{~min})$, fixed in Baker's formol (4\% [v/v] formaldehyde, $2 \%[\mathrm{w} / \mathrm{v}]$ sodium chloride and $1 \%[\mathrm{w} / \mathrm{v}]$ calcium acetate) for 30 min (Pipe et al. 1995, Dyrynda et al. 1998). The neutral red was then extracted by the addition of $100 \mu \mathrm{l}$ acetic acid/ethanol solution to each well, which was left to stand for $30 \mathrm{~min}$, after which the plates were quantified at $490 \mathrm{~nm}$ with a Tecan fluorospectrophotometer. Three hemolymph samples per mussel were analyzed and the mean of these samples was used for statistical analyses. To test the effect of the incubation period on the LR response, the same protocol was replicated using only $30 \mathrm{~min}$ incubation in dark at room temperature.

Phagocytic activity (PA): Microscopic observation: Microscopic observations of PA were performed as previously described for Expt 1.

Spectrophotometric observations: Aliquots of $100 \mu \mathrm{l}$ of hemolymph/TBS were added to microplates. Twenty $\mu \mathrm{l}$ of neutral-red stained zymosan type 1 yeast, $2.3 \times$ $10^{8}$ particles $\mathrm{ml}^{-1}$, were added to each well for $30 \mathrm{~min}$ incubation, after which $100 \mu \mathrm{l}$ of fixative was added for 30 min (Pipe et al. 1995, Dyrynda et al. 1998). The plates were washed twice with TBS by centrifugation $(1000 \times g$ for $5 \mathrm{~min})$ and the neutral red was solubilized by adding $100 \mu \mathrm{l}$ of extraction solution for $30 \mathrm{~min}$. The microplates were read at $490 \mathrm{~nm}$, using a spectrophotometer (Molecular Devices). All readings were adjusted for cell numbers. Three hemolymph samples per mussel were analyzed and the mean of these samples was used for statistical analysis.

Bacterial challenge: The bacterial challenge was performed after a $13 \mathrm{~d}$ exposure with the following modifications from Expt 1. The inoculation was performed in a cold room $\left(12^{\circ} \mathrm{C}\right)$ to minimize temperature shock for the mussels. The inoculum $(0.5 \mathrm{ml}$ for adults and $0.1 \mathrm{ml}$ for juveniles) was injected directly into the hemolymph for adults and into the visceral mass for juveniles. After inoculation, the mussels were put back into their aquaria (previously drained) without elastic bands. After $2 \mathrm{~h}$, the aquariums were slowly refilled with clean, UV-sterilized, flow-through seawater. Three separate hemolymph samples per mussel were taken on Day 6, analyzed for bacterial number as described above and the mean of these 3 counts was used for the statistical analysis.

Statistical analysis. Statistical analysis used SPSS and Systat softwares for a PC. Distributions of variables were examined for normality in probability plots and tested with Levine's test. Homogeneity of variances among groups to be compared were tested by $F$-test. Where required, data were transformed to their logarithms except for the percentage data, which were transformed using the arcsine square root.

Expt 1: Differences among treatment and control groups for all end-points (MI, LR, PA and HC) were determined using a repeated measure analysis of variance (ANOVA) with time $(0,1,4,11,18,25$ and $32 \mathrm{~d})$ and TBT or DBT concentrations $(0,5,10,20,40$ and $80 \mathrm{ng} \mathrm{Sn} \mathrm{l}^{-1}$ ) as independent variables. Where significant effects $(p<0.05)$ of dose were detected, or dose interacted significantly with sampling day, days were analyzed separately by 1 -way ANOVA followed by an a posteriori test (least significant difference of means) to determine the doses or days on which treatment and control groups differed.

To establish whether the 2 chemicals, TBT or DBT, affected the end-points differently, we pooled doses (omitting the 0 dose) and did an ANCOVA with day as the covariate and chemical as the principal variable. If the analysis showed significant interactions (i.e. chemicals had different effects over days), ANCOVAs were performed on each dose separately to determine whether all doses or only some doses differed over time. Where interactions were found in dose-specific analyses, they were described. Where no interactions were found, the intercept was tested to determine whether or not the chemicals differed in effect over all days.

In addition, to determine whether both chemicals were capable of achieving the same maximal effect (i.e. a threshold) impacts of TBT and DBT on the day of greatest effect were compared in 2 ways. First, chemical (TBT vs DBT) and dose were compared in a 2-way ANOVA. Second, maximal responses directed by each chemical were compared by 1-way ANOVA. The first analysis tested whether both chemicals were effective at a similar dose. The second analysis tested whether 
both chemicals achieved the same maximal effect. Significant differences are reported where $p<0.05$.

Differences in bacterial counts among treatment and control groups for bacterial challenge were determined by a 2-way ANOVA with time ( 4 and $14 \mathrm{~d}$ ) and TBT or DBT concentrations $\left(0,5,10,20,40\right.$ and $\left.80 \mathrm{ng} \mathrm{Sn}^{-1}\right)$ as independent variables. As for the previous assays, where significant effects $(p<0.05)$ of dose were detected, or dose interacted significantly with day, days were analyzed separately by 1-way ANOVA followed by an a posteriori test (least significant difference of means) to determine the doses or days on which treatment and control groups differed. To compare TBT to DBT impacts, the ANCOVA was performed exactly as described above with the exception that no maximal effect impacts of TBT or DBT were compared.

Expt 2: Differences among treatment and control groups (LR, PA and HC) were determined by a 2-way ANOVA with time $(0,1,6$ and $13 \mathrm{~d})$ and TBT or DBT concentrations $\left(0,40\right.$ and $\left.80 \mathrm{ng} \mathrm{Sn}^{-1}\right)$ as independent variables. All other analyses were performed as described above.

Differences among treatment and control groups for bacterial challenge were determined as previously described with age (juvenile and mature) and TBT or DBT concentrations $\left(0,40\right.$ and $\left.80 \mathrm{ng} \mathrm{Sn}^{-1}\right)$ as independent variables. Where significant effects $(p<0.05)$ of dose were detected or dose interacted significantly with age, ages were analyzed separately by 1-way ANOVA followed by an a posteriori test (least significant difference of means) to determine the doses for which treatment and control groups differed.

\section{RESULTS}

\section{Membrane injury (MI)}

When observed microscopically, we detected 3 general shapes of hemocytes grading from normal to severely damaged: (1) normal, with filipod projections and visible ectoplasm; (2) naivelike (rounded) with no filipod; and (3) short, with blunt projections either tightly spaced or interspersed with rough, blebbing membrane, resembling hemocytes kept in hypo-osmotic conditions. In addition, cellular debris and dark unidentified small bodies were present in all pooled or exposed samples.

For both TBT and DBT, MI over time differed with dose (time $\times$ dose interaction for TBT and DBT, respectively: $F_{30,144}=6.43, \mathrm{p}<0.001$; $F_{30,144}=7.56, \mathrm{p}<0.001$; Fig. 1). Therefore, effects of dose were examined on each sampling date separately. For TBT, doses $\geq 10 \mathrm{ng} \mathrm{Sn} \mathrm{l}^{-1}$ produced significant elevation in MI by Day 1, which was maintained through the end of the experiment on Day 32. Furthermore, within the first $4 \mathrm{~d}$ of exposure, the degree of MI was generally dose-responsive (e.g. 40 and $80 \mathrm{ng} \mathrm{Sn}^{-1}$ produced significantly higher MI than the lower doses). By Day 11, significant MI elevation was also seen in the $5 \mathrm{ng} \mathrm{Sn} \mathrm{l}^{-1}$ treatment and by Day 18 the MI produced by all doses was similar and plateaued at 40 to $50 \%$ of hemocytes showing MI.

DBT had less impact on MI than TBT (Fig. 1). By

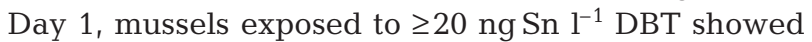
significantly higher MI than unexposed mussels or those exposed to lower doses. By Day 4, MI was significantly elevated in all groups exposed to DBT and this was maintained through to the end of the exposure. Within mussels exposed to DBT, degree of MI was related to dose. On Day 11, the $80 \mathrm{ng} \mathrm{Sn} \mathrm{l}^{-1}$ group showed a significantly higher $\mathrm{MI}$ than groups exposed to the lower doses; on Days 18 and 32, mussels exposed to $\geq 10 \mathrm{ng} \mathrm{Sn} \mathrm{l}^{-1} \mathrm{DBT}$ showed higher MI than those

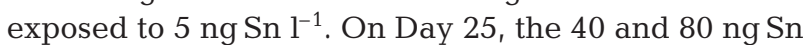
$\mathrm{l}^{-1}$ groups showed higher MI than the lower dose groups.

Statistical comparison of the impacts of TBT and DBT on $\mathrm{MI}$ revealed that all doses of TBT produced more rapid MI than DBT (chemical $\times$ time interaction for dose-specific analyses: $F_{6,56}=2.59$ to $5.51, \mathrm{p}=$ 0.027 to $<0.001$ ). To determine whether or not the magnitude of MI differed between TBT and DBT, responses at the end of the exposure were examined by 2-way ANOVA (i.e. chemical and dose effects on MI). Over all doses, TBT did not produce more MI than $\operatorname{DBT}\left(F_{1,48}=2.11, \mathrm{p}=0.080\right)$. A maximum limit of $\mathrm{MI}$ appeared with $80 \mathrm{ng} \mathrm{Sn} \mathrm{l}^{-1}$ of TBT and DBT as both produced the same degree (ca. $44 \%)$ of $\mathrm{MI}\left(F_{1,8}=0.84\right.$, $\mathrm{p}=0.39$ ).
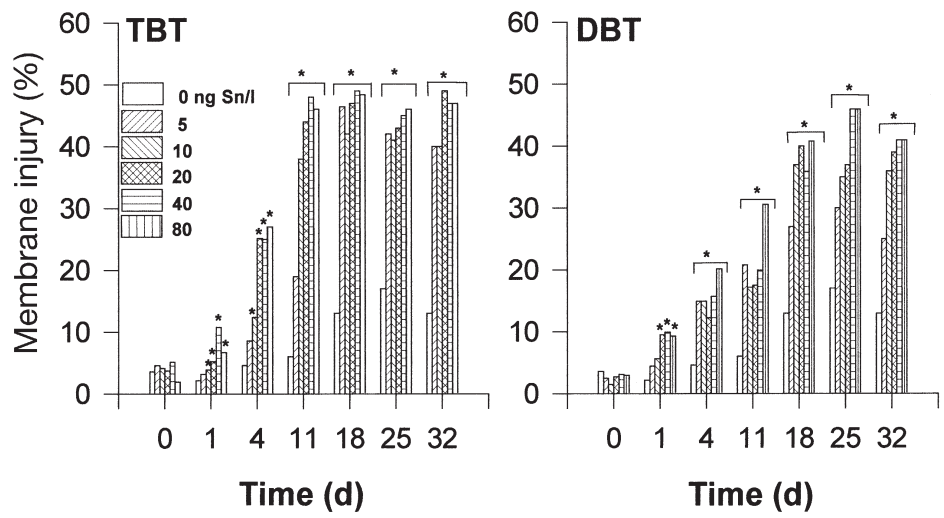

Fig. 1. Membrane injury (MI) observed from 5 pools of 4 mussels sampled after $0,1,4,11,18,25$ and $32 \mathrm{~d}$ of exposure to tributyltin (TBT) and dibutyltin (DBT). Asterisks represent individual or groups of values (in brackets) significantly different from controls. SD are not indicated for clarity of all figures 


\section{Phagocytic activity (PA)}

As for MI, the effect over time of both butyltins on phagocytosis, as determined by microscopic observation in Expt 1, differed with dose (time $\times$ dose interaction for TBT: $F_{30,144}=4.24, \mathrm{p}<0.001$; for DBT: $F_{30,144}=$ $4.27, \mathrm{p}<0.001)$. The day-by-day analysis of the trends for TBT are shown in Fig. 2.1a. By Day 1, PA was significantly reduced in the 3 highest dose groups $(20,40$ and $80 \mathrm{ng} \mathrm{Sn} \mathrm{l}^{-1}$ ) relative to the lower doses and control. By Day 4, all TBT doses except $5 \mathrm{ng} \mathrm{Sn} \mathrm{l}^{-1}$ showed significant reduction in phagocytosis, and by Day 18 , even $5 \mathrm{ng} \mathrm{Sn} \mathrm{l}^{-1}$ was significantly depressed relative to the control. Reduced phagocytosis persisted through to the end of the experiment and degree of reduction was dose-responsive. The highest dose of TBT tested (80 $\mathrm{ng} \mathrm{Sn}^{-1}$ ) produced a significantly higher reduction in phagocytosis than the 2 lowest doses ( 5 and $10 \mathrm{ng} \mathrm{Sn}$ $\mathrm{1}^{-1}$ ) by Day 32.

DBT appeared slower to affect phagocytosis than TBT but ultimately had the same result (Fig. 2.1b). No significant depression of phagocytosis was observed until Day 18, from which time until the end of the experiment all doses of DBT significantly reduced PA.

Comparison of the impacts of TBT and DBT on phagocytosis revealed that for all doses greater than $5 \mathrm{ngSn} \mathrm{l}^{-1}$, TBT produced more rapid reduction in phagocytosis than DBT (chemical $\times$ time interaction for dose-specific analyses: $F_{6,56}=3.00$ to $5.09, \mathrm{p}=$ 0.012 to $<0.001$ ). To determine whether the magnitude of reduction in phagocytosis differed between TBT and DBT, responses at the end of the exposure were examined by 2 -way ANOVA (i.e. chemical and dose effects on phagocytosis). Over all doses, there was no difference between the effects of TBT and DBT on PA $\left(F_{1,40}=2.25, \mathrm{p}=0.081\right)$ and the maximal reduction in PA (only $53 \%$ of cells exposed to $80 \mathrm{ng} \mathrm{Sn} \mathrm{l}^{-1} \mathrm{TBT}$ or DBT actively phagocytosing) did not differ between TBT and DBT $\left(F_{1,8}=2.45 \mathrm{p}=0.156\right)$.

In Expt 2, the effect over time of both butyltins on phagocytosis, as determined by microscopic evaluation, differed with dose (time $\times$ dose interaction for TBT: $F_{6,48}=5.98, \mathrm{p}<0.001$; for DBT: $F_{6,48}=6.52, \mathrm{p}<$ 0.001). The daily analysis showed that by Day 1 , PA was significantly reduced by both doses (40 and $80 \mathrm{ng} \mathrm{Sn}^{-1}$ ) of TBT but did not differ between them and that was maintained until the end of exposure (Fig. 2.2a). Significant depression of phagocytosis was observed on Day 1 for DBT (Fig. 2.2b), but only for

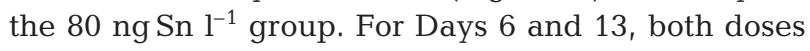
of DBT significantly reduced PA. Comparison of the impacts of TBT and DBT on PA did not show any difference between the butyltins for all doses combined.

The effect over time of both butyltins on phagocytosis, as determined by spectrophotometric tech-
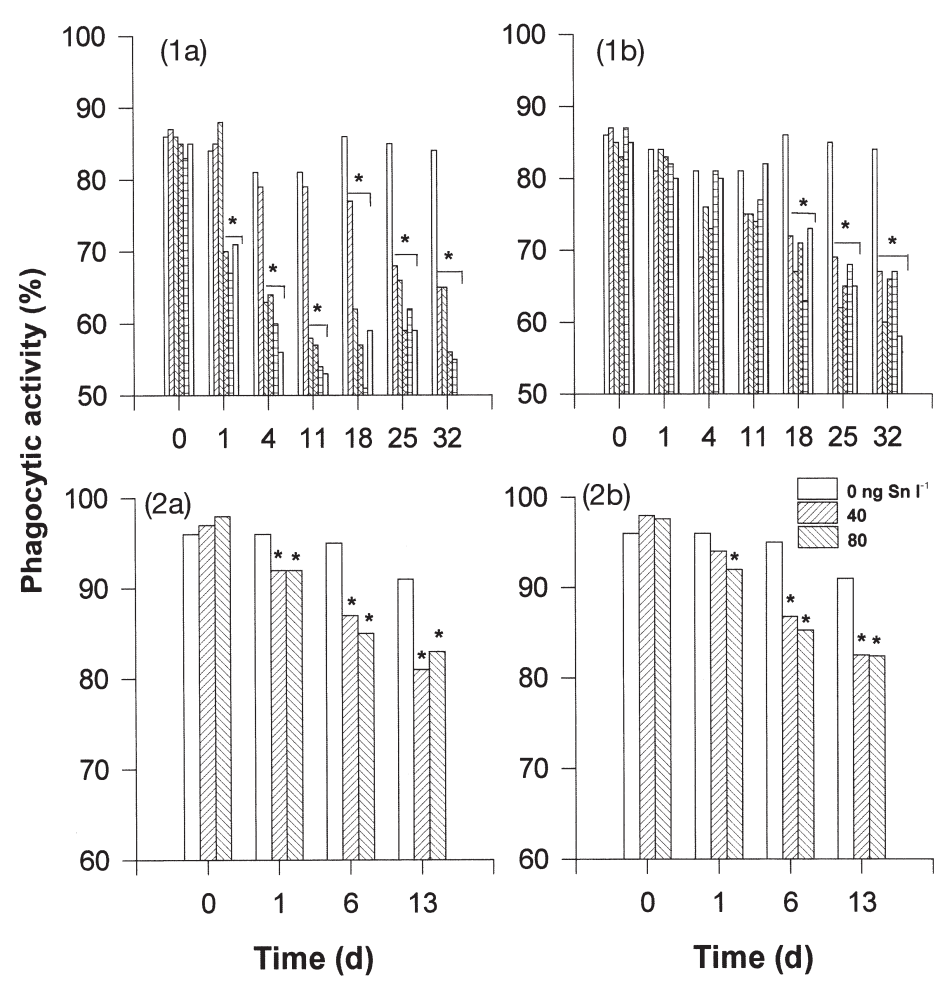

Fig. 2. Phagocytic activity (PA) measured by microscopic observations. In Expt 1, PA was measured from 5 pools of 4 mussels sampled after $0,1,4,11,18,25$ and $32 \mathrm{~d}$ of exposure to TBT (1a) and DBT (1b). In Expt 2, PA was measured from 10 mussels sampled after 0,6 and $13 \mathrm{~d}$ of exposure to TBT (2a) and DBT (2b). Asterisks represent individual or groups of values (in brackets) significantly different from controls

nique, differed with dose (time $\times$ dose interaction for TBT: $F_{6,108}=7.17, \mathrm{p}<0.001 ;$ for DBT: $F_{6,108}=2.19, \mathrm{p}=$ 0.049 ; results not shown). The day-by-day analysis of the trends for TBT revealed the following. On Days 6

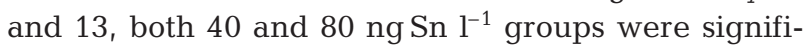
cantly elevated in comparison to the control group but significantly different from each other only on Day 13. A significant elevation of PA on Day 1 compared to the other groups was induced by $80 \mathrm{ng} \mathrm{Sn} \mathrm{l}^{-1}$. From Day 6 , both doses of DBT significantly increased PA over controls and to a degree not significantly different. The apparent discrepancy between the results obtained by microscopic and spectrophotometric methods are discussed below. Comparison of the impacts of TBT and DBT on PA revealed no significant difference between the 2 toxicants.

\section{Lysosome retention (LR)}

In Expt 1, the impact of the butyltins on LR (Fig. 3.1) was not monotonic over time, resulting in a significant 

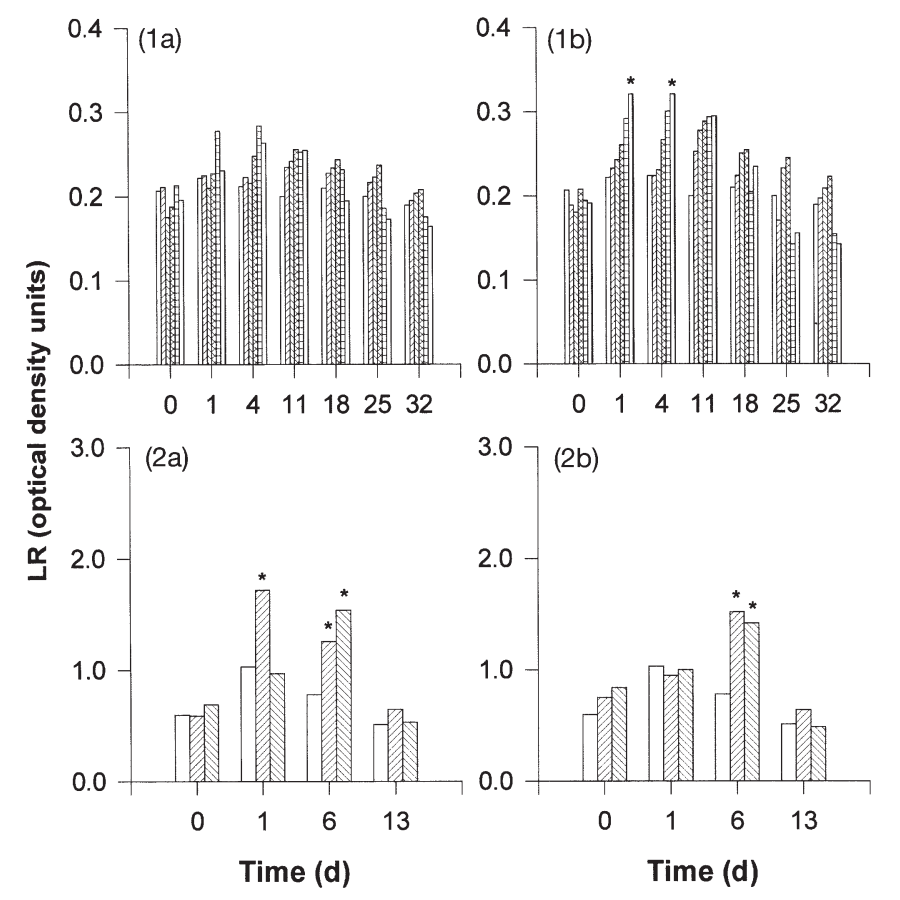

Fig. 3. Lysosome retention (LR). In Expt 1, LR was measured from 5 pools of 4 mussels sampled after $0,1,4,11,18,25$ and $32 \mathrm{~d}$ of exposure to TBT (1a) and DBT (1b). In Expt 2, LR was measured after $4 \mathrm{~h}$ incubation time from 10 mussels sampled after $0,1,6$ and $13 \mathrm{~d}$ of exposure to TBT (2a) and DBT (2b). Asterisks represent individual or groups of values (in brackets) significantly different from controls

interaction between time and dose for $\operatorname{DBT}\left(F_{30,144}=\right.$ $2.53, \mathrm{p}<0.001)$ and time effect for TBT $\left(F_{6,144}=6.74\right.$, $\mathrm{p}<0.001$ ). Exposure to higher doses of TBT (40 and $80 \mathrm{ng} \mathrm{Sn}^{-1}$ ) had a tendency to raise LR on Days 1 and 4 followed by a reduction below control levels by Days 18 through to 32 (Fig. 3.1a). However, none of these differences was statistically significant. DBT also produced a rise and fall in LR, but with a greater amplitude than TBT (Fig. 3.1b). On Days 1 and 4, the

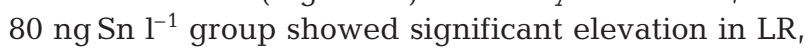
which disappeared by Day 18. Levels of LR then continued to fall in the 2 highest doses of DBT reaching significantly lower levels than the $20 \mathrm{ng} \mathrm{Sn} \mathrm{l}^{-1}$ treatment by Day 25 and remaining low through Day 32, although differences were no longer significant. No significant differences were detected between the effects over time of TBT and DBT on LR.

As in Expt 1, the impact of the butyltins on LR in Expt 2 was not monotonic over time, resulting in significant interactions between time and dose for both TBT and DBT: TBT $\left(F_{6,108}=7.17, \mathrm{p}<0.001\right)$ and $\left(F_{6,108}=\right.$ $4.22, \mathrm{p}<0.001)$ for the $30 \mathrm{~min}$ and $4 \mathrm{~h}$ assays, respectively; $\operatorname{DBT}\left(F_{6,108}=3.45, \mathrm{p}<0.001\right)$ and $\left(F_{6,108}=2.66\right.$, $\mathrm{p}=0.019$ ) for the $30 \mathrm{~min}$ and $4 \mathrm{~h}$ assays, respectively. As results were similar for incubation times of $30 \mathrm{~min}$ and $4 \mathrm{~h}$, only the $4 \mathrm{~h}$ data are shown in Fig 3.2 for direct comparison with Expt 1. TBT significantly raised LR on

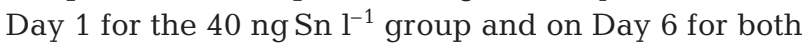

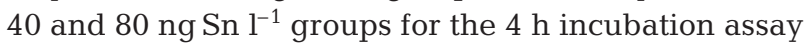
(Fig. 3.2a). On Day 13, there was no significant difference between the groups anymore. Similarly, exposure to doses of 40 and $80 \mathrm{ng} \mathrm{Sn} \mathrm{l}^{-1}$ TBT significantly raised LR, but with a lesser magnitude, on Days 6 and 13 for the 30 min incubation assay (results not shown). DBT also produced a rise and fall in LR (Fig. 3.2b). LR was significantly elevated on Day 6 by 40 and $80 \mathrm{ng} \mathrm{Sn} \mathrm{l}^{-1}$ DBT. By Day 13, no significant difference was detected among treatment groups. Exactly the same patterns were observed with the $30 \mathrm{~min}$ incubation as with the $4 \mathrm{~h}$ incubation time.

The ANCOVA for the $4 \mathrm{~h}$ incubation assay revealed no difference in the effect of TBT and DBT in the 80 ng Sn $1^{-1}$ groups (intercept: $F_{1,72}=0.006, p=0.941$ ).

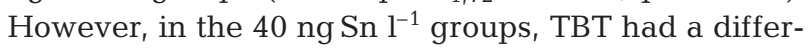
ent effect over time from DBT (intercept: $F_{3,72}=5.21$, $p=0.003)$. The maximal effect on LR achieved by $40 \mathrm{ng} \mathrm{Sn}^{-1}$ DBT was smaller than the maximal effect achieved by $40 \mathrm{ng} \mathrm{Sn} \mathrm{l}^{-1}$ TBT (ANOVA on TBT Day 1 vs DBT Day 6: $F_{1,18}=45.56, \mathrm{p}<0.001$ ). Finally, it should be mentioned that for the $30 \mathrm{~min}$ incubation assay, the ANCOVA revealed that overall TBT had a greater impact on LR than DBT (intercept: $F_{1,157}=5.55, \mathrm{p}=$ 0.020).

\section{Hemocyte counts (HC)}

Effects of butyltins on HC in Expt 1 were less clear than effects on MI, phagocytosis or LR. The effect of TBT on HC over time differed with dose (time $\times$ dose interaction: $\left.F_{30,144}=2.14, \mathrm{p}=0.002\right)$. DBT effects on HC differed with dose $\left(F_{5,24}=3.54, \mathrm{p}=0.015\right)$ and time $\left(F_{6,144}=8.33, \mathrm{p}<0.001\right)$ without interaction $\left(F_{30,144}=\right.$ $1.44, \mathrm{p}=0.080$ ). Daily comparisons of $\mathrm{HC}$ in mussels exposed to different doses of TBT (Fig. 4.1a) revealed

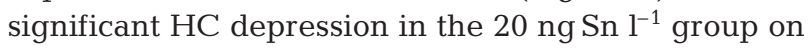
Day 1. By Day 4, the $80 \mathrm{ng} \mathrm{Sn} \mathrm{l}^{-1}$ group was elevated

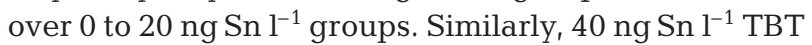

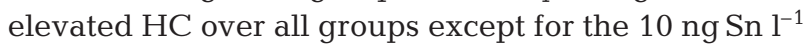
on Day 4. Only the $40 \mathrm{ng} \mathrm{l}^{-1}$ group was above all other groups on Day 18. On day 32, HC were significantly lower than control levels in all TBT-exposed groups except for the highest dose (80 $\left.\mathrm{ng} \mathrm{Sn}^{-1}\right)$.

For DBT, ANOVA failed to detect any significant difference in the $\mathrm{HC}$ between treatment groups on Days 1, 4, 18 and 25. HC was elevated on Day 11 for

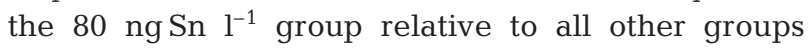
except the $40 \mathrm{ng} \mathrm{Sn} \mathrm{l}^{-1}$. On Day 32, the HC was signif-

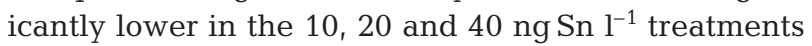
than in the control. However, the $\mathrm{HC}$ in the $80 \mathrm{ng} \mathrm{Sn} \mathrm{l}^{-1}$ 

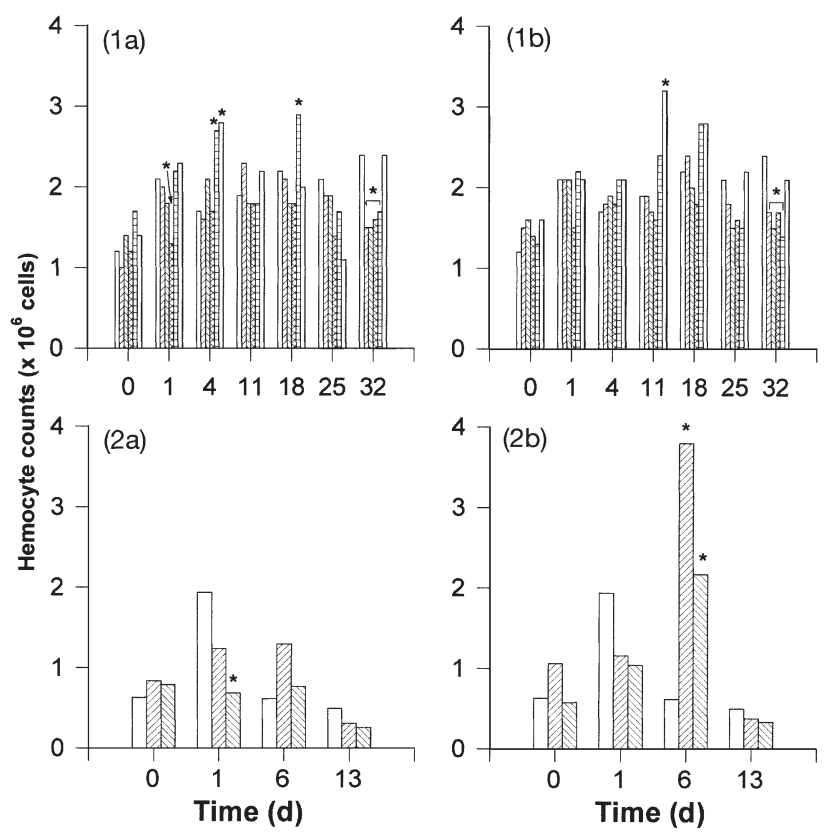

Fig. 4. Hemocyte counts (HC). In Expt 1, hemocytes were counted from 5 pools of 4 mussels sampled after $0,1,4,11,18$, 25 and $32 \mathrm{~d}$ of exposure to TBT (1a) and DBT (1b). In Expt 2, hemocytes came from 5 pools of 2 mussels sampled after 0,1 , 6 and $13 \mathrm{~d}$ of exposure to TBT (2a) and DBT (2b). Asterisks represent individual or groups of values (in brackets) significantly different from controls

group was similar to the control level and significantly

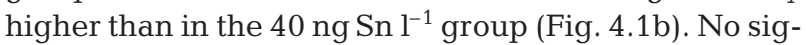
nificant differences were detected in comparing the effects of TBT and DBT on HC over time.

As reported for Expt 1, effects of butyltins on $\mathrm{HC}$ in Expt 2 were obscured by a large variability within each group (Fig. 4.2). The effect of TBT on HC over time differed with dose in both assays (time $\times$ dose interaction: $F_{6,48}=2.45, \mathrm{p}=0.038$ for the pooled hemolymph and $F_{6,106}=1.85, p=0.047$ for the non-pooled). Daily comparisons of $\mathrm{HC}$ in mussels exposed to TBT in the pooled samples revealed significant depression of HC in the $80 \mathrm{ng} \mathrm{Sn} \mathrm{l}^{-1}$ group on Day 1 (Fig. 4.2a). The nonpooled samples revealed a significant depression in

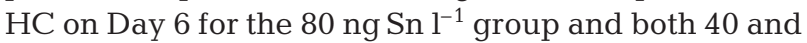
$80 \mathrm{ng} \mathrm{Sn}^{-1}$ groups on Day 13 (results not shown).

DBT effects on HC over time also differed with dose for both the pooled hemolymph $\left(F_{6,48}=7.01, \mathrm{p}<0.001\right)$ and the non-pooled hemolymph $\left(F_{6,105}=3.71 \mathrm{p}=\right.$ 0.002). HC in the pooled samples was elevated by both doses of DBT on Day 6 and was significantly more elevated by 40 than $80 \mathrm{ng} \mathrm{Sn}^{-1}$ (Fig. 4.2b). For the nonpooled hemolymph, the 40 and $80 \mathrm{ng} \mathrm{Sn} \mathrm{l}^{-1}$ groups showed a significant elevation in HC by Day 1 which was maintained to Day 13 (results not shown).
In the pooled samples, DBT had a more pronounced effect than TBT on HC (chemical $\times$ time interaction: $F_{3,32}=4.33$ to $4.21, \mathrm{p}=0.013$ to 0.011 ) for 40 and $80 \mathrm{ng} \mathrm{Sn} \mathrm{l}^{-1}$, respectively. The timing of TBT and DBT action on HC was different for both doses; for both doses there was a rise between Days 1 and 6 in DBT, which was absent for TBT. Furthermore, HC in mussels exposed to both doses of DBT, was significantly higher on Day 6 than HC in mussels exposed to comparable levels of TBT (ANOVA: $F_{1,8}=12.06$ to 11.45 , $\mathrm{p}=0.008$ to 0.010 for 40 and $80 \mathrm{ng} \mathrm{Sn}^{-1}$, respectively). In the non-pooled samples, the ANCOVA revealed that DBT overall had a greater impact on HC than TBT (intercept: $F_{1,154}=6.57, \mathrm{p}=0.011$ ).

\section{Bacterial clearance}

Clearance of labeled Listonella anguillarum in Expt 1 was impeded by a previous $32 \mathrm{~d}$ exposure to TBT or DBT. Four d after the inoculation, counts of $L$. anguillarum were higher in mussels pre-exposed to 10 ,

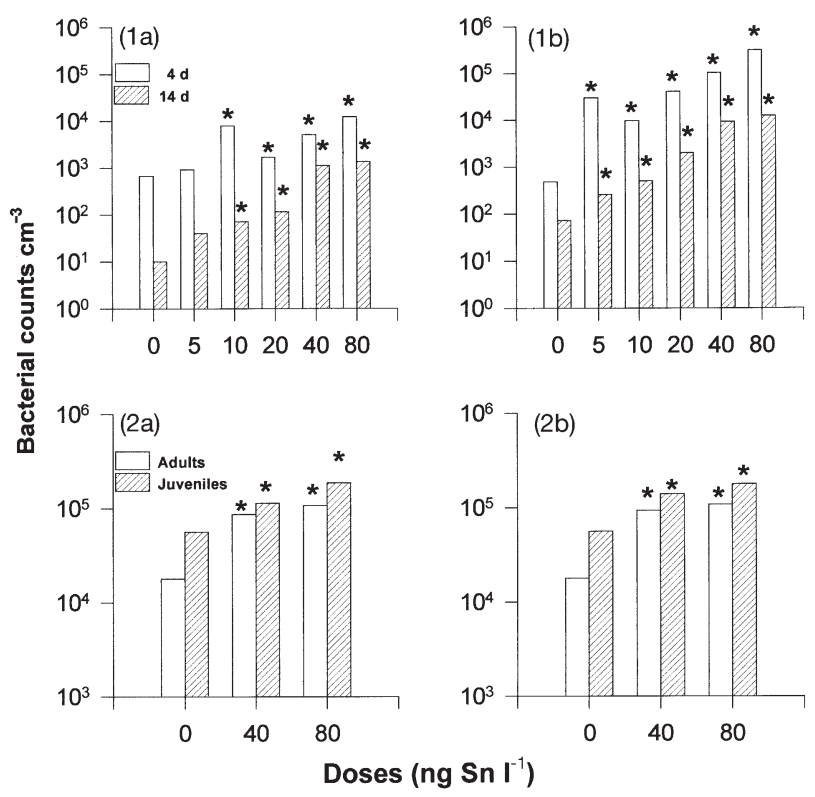

Fig. 5. Effects of pre-exposure of blue mussels to butyltins on their bacterial clearance capacity. In Expt 1, mussels were exposed for $32 \mathrm{~d}$ to various doses of TBT (1a) or DBT (1b) doses before the bacterial test. Bacteria were counted $4 \mathrm{~d}$ (light gray bars) and $14 \mathrm{~d}$ (dark gray bars) after the injection of the common bacterium Listonella anguillarum (Vibrio) at the end of the pre-exposure. In Expt 2, mussels were exposed for $13 \mathrm{~d}$ to TBT (2a) or DBT (2b) doses before the challenge test. Bacteria were counted for adults (light gray bars) and juveniles (dark gray bars) $6 \mathrm{~d}$ after injection of the common bacterium L. anguillarum (Vibrio). Bars are mean responses of 10 mussels. Asterisks indicate significant elevation over respective control 
40 and $80 \mathrm{ngSn}^{-1}$ TBT than in the control and the 5 ng Sn l$^{-1}$ groups (Fig. 5.1a). Though bacterial counts dropped between Days 4 and 14 in mussels exposed to TBT $\left(F_{1,90}=11.532, \mathrm{p}=0.036\right)$, they were still significantly elevated over controls in mussels exposed to $\geq 20 \mathrm{ng} \mathrm{Sn}^{-1}$ TBT and were significantly higher in the

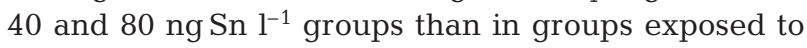
lower doses. Mussels exposed to all doses of DBT showed significantly higher counts of $L$. anguillarum than controls 4 and $14 \mathrm{~d}$ after infection $\left(F_{1,90}=72.691\right.$, $\mathrm{p}=0.012$ ) (Fig. 5.1b). Furthermore, by Day 14, groups exposed to 20 to $80 \mathrm{ng} \mathrm{Sn} \mathrm{l}^{-1}$ still maintained significantly higher levels of bacteria than controls and the $5 \mathrm{ng} \mathrm{Sn}^{-1}$ group. No significant differences in chemical species on bacterial clearances were detected over time.

The effect of TBT dose and age of mussel (adult vs juvenile) on clearance of Listonella anguillarum in Expt 2 were analyzed using 2-way ANOVA. The effect of TBT dose differed with age of mussel (interaction term: $\left.F_{2,54}=7.76, \mathrm{p}=0.001\right)_{\text {i }}$ juveniles showed a greater effect than adults (Fig. 5.2a). Both age groups showed significantly elevated bacterial counts $6 \mathrm{~d}$ after inoculation when pre-exposed to 40 or $80 \mathrm{ng} \mathrm{Sn}^{-1} \mathrm{TBT}$ and this effect was greater in the $80 \mathrm{ng} \mathrm{Sn} \mathrm{l}^{-1}$ than the $40 \mathrm{ng} \mathrm{Sn}^{-1}$ group $\left(F_{2,27}=68.26\right.$ to $48.25, \mathrm{p} \leq 0.001$ for mature and juvenile mussels, respectively).

Bacterial levels were higher in juvenile than in mature mussels exposed to DBT (Age: $F_{1,54}=41.09, \mathrm{p}<$ 0.001 ) (Fig. 5.2b). Both age groups showed significantly higher Listonella anguillarum counts $6 \mathrm{~d}$ after inoculation when previously exposed to 40 or $80 \mathrm{ng} \mathrm{Sn}$

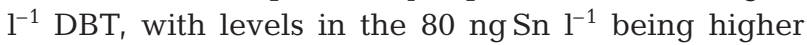
than in the $40 \mathrm{ngSn} \mathrm{l}^{-1}$ group $\left(F_{2,27}=10.87\right.$ to 23.23 , $\mathrm{p}<0.001$ for mature and juvenile mussels, respectively). As for Expt 1, no significant differences were detected between the $L$. anguillarum clearance in all groups previously exposed to either TBT or DBT.

Table 1. Tributyltin (TBT) and dibutyltin (DBT) accumulation in blue mussels exposed to waterborne TBT or DBT for $32 \mathrm{~d}$ for Expt 1 and $13 \mathrm{~d}$ for Expt 2. Each value is the mean of 3 replicate analysis of the pooled soft tissues of 20 mussels (Expt 1) or 10 mussels (Expt 2) $\pm \mathrm{SD}$. Results expressed as ng Sn $\mathrm{g}^{-1}$ of tissue (dry wt). Traces represent detected TBT or DBT between the instrumental detection limit $\left(1 \mathrm{ng} \mathrm{Sn} \mathrm{g}^{-1}\right)$ and the quantification limit $\left(5 \mathrm{ng} \mathrm{Sn}^{-1}\right)$

\begin{tabular}{|c|c|c|c|c|c|c|}
\hline \multirow{3}{*}{$\begin{array}{l}\text { Doses } \\
\left(\mathrm{ng} \mathrm{Sn} \mathrm{l}^{-1}\right)\end{array}$} & \multicolumn{6}{|c|}{ Treatments } \\
\hline & & Expt 1 & & & Expt 2 & \\
\hline & $\begin{array}{c}\text { TBT } \\
\text { as TBT }\end{array}$ & as DBT & $\begin{array}{c}\text { DBT } \\
\text { as DBT }\end{array}$ & $\begin{array}{c}\text { TBT } \\
\text { as TBT }\end{array}$ & as DBT & $\begin{array}{c}\text { DBT } \\
\text { as DBT }\end{array}$ \\
\hline 0 & $\leq 1$ & $\leq 1$ & $\leq 1$ & $\leq 1$ & $\leq 1$ & $\leq 1$ \\
\hline 5 & $\leq 1$ & $\leq 1$ & $\leq 1$ & - & - & - \\
\hline 10 & Traces & $\leq 1$ & Traces & - & - & - \\
\hline 20 & Traces & $\leq 1$ & Traces & - & - & - \\
\hline 40 & $50 \pm 13$ & Traces & $50 \pm 13$ & $23 \pm 1$ & Traces & Traces \\
\hline 80 & $45 \pm 12$ & $25 \pm 9$ & $45 \pm 12$ & $248 \pm 34$ & Traces & Traces \\
\hline
\end{tabular}

\section{Chemical analysis}

Concentrations of butyltins found in each group of mussels at the end of the 2 experiments are presented in Table 1. TBT and DBT were detected but not quantified (traces) in mussels exposed to concentrations of

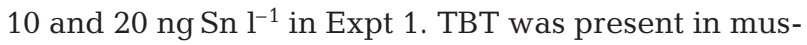
sels exposed to 40 and $80 \mathrm{ng} \mathrm{Sn} \mathrm{^{-1 }}$, but DBT was also present in these mussels indicating in vivo dealkylation in progress. In Expt 2, TBT was present in mussels exposed to TBT with only traces of DBT present. Mussels exposed to DBT showed only traces of the compound, indicating a fast elimination process.

\section{DISCUSSION}

This study demonstrated time- and dose-responsive effects of environmentally relevant concentrations of TBT and DBT on the internal defense of blue mussels, as well as a dose responsive impairment in clearing Listonella anguillarum from the hemolymph. The 2 different experiments conducted at different periods of the year, using different techniques for certain endpoints, gave generally comparable results as did a lowest observed effect level (LOEL) experiment reported in St-Jean et al. (2002, this issue).

Butyltin concentrations accumulated by blue mussels in this study were environmentally realistic for coastal areas. Tissue concentrations of TBT in mussels are considered moderately high in the 170 to $609 \mathrm{ngSn} \mathrm{g}^{-1}$ dry wt range and chronicly below 170 ng Sn g ${ }^{-1}$ dry wt (Page \& Widdows 1991). The highest level of TBT accumulation reached in this study was $45.2 \mathrm{ng} \mathrm{Sn} \mathrm{g}^{-1}$ dry wt for mussels exposed to

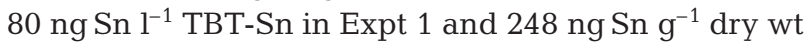
for Expt 2. Differences observed in TBT and DBT accumulation between the 2 experiments might be attributed to the longer exposure period in Expt 1, and to the in vivo dealkylation of TBT, clearly observed in Expt 1 but not yet in place after $13 \mathrm{~d}$ in the Expt 2 . Mussels exposed to DBT showed no detectable accumulation after $13 \mathrm{~d}$ but showed clear evidence of accumulation after $32 \mathrm{~d}$, indicating a faster clearing rate for DBT than TBT.

In both experiments, we observed MI in hemocytes from all groups following exposure to butyltins. MI was particularly severe in Expt 1 including control groups, suggesting an influence of external stressors in addition to butyltins. MI was also observed in pooled hemolymph samples of Expt 2, albeit at lower 
incidence than Expt 1, but was much less common in non-pooled samples. No MI was observed in the control mussels. Between the 2 protocols used, the pooled samples consistently showed greater MI than the nonpooled samples. However, the behavior of allogenic hemolymph transfer in bivalves is unknown. Ey \& Jenkin (1982) have shown non-self recognition directed towards invading microorganisms, damaged tissue and foreign material. In addition to greater MI, the pooled samples always showed more debris and lower HC than non-pooled samples. This suggests that MI was enhanced in Expt 1 by the pooling of hemocytes from 4 different individuals. Although it remains to be verified, these hemocytes may have reacted to foreign hemocytes by membrane attack.

Previous studies have reported that hemocytes exposed to organotin compounds sustain varying degrees of membrane damage ranging from cell rounding, interfering with aggregation and locomotion (Auffret \& Oubella 1997, Oubella 1997) to cytoskeletal damage causing important shape changes (Porvaznik et al. 1986). Our results are consistent with these reports; butyltin-exposed samples showed less aggregation than the controls. Levels of MI were smaller and occurred more slowly in our study than those found in ascidian hemocytes (Cima et al. 1998) or human erythrocytes (Gray et al. 1986, 1987, Porvaznik et al. 1986) exposed to TBT concentrations much higher than ours. However, various levels of MI have been observed at comparable butyltin concentrations in blood cells of rainbow trout Oncorhynchus mykiss (C. Ribiero, J. Padros \& É. Pelletier unpubl. results) and amaebocytes of starfish Leptasterias polaris (É. Pelletier unpubl. results).

Triorganotins are known to be membrane-active molecules (Zucker et al. 1988) which bind to membrane proteins and phospholipids and modify the permeability (Oubella 1997). The action of butyltins on MI could be explained by the following. First, Ambrosini et al. (1996) suggested that organotin compounds dissolved in aqueous solution form different cations, depending on the number of ligands. These differences (types and number of ligands) influence the polarity and the structural characteristics of each organotin and could explain the different actions at the phospholipidmembrane level. These authors showed that a triorganotin (triphenyltin: TPT) affects the membrane lipids at the hydrophobic core of the membrane bilayer while DBT affects lipids on the membrane's polar surface. In addition, Akhtar et al. (1987) showed TBT to bind to an anion exchanger with greater affinity than DBT, while DBT has been shown to have a higher affinity than TBT with sulphidryl groups associated with membranes or cytoskeleton (Boyer 1989, Saboori \& Newcombe 1992). Therefore, it is hypothesized that the organotins influence different domains of the membrane lipids and thus have different effects on membrane fluidity and the degree of damage to cell function.

Secondly, both organotins, but especially DBT, were also shown to shut down the $\mathrm{Ca}^{2+}$ pump (Gray et al. 1987, Cima et al. 1998). Bouchard et al. (1999) hypothesized that DBT appears to be a better competitor for calcium sites than TBT because the ionic form of DBT is a double-charged cation like $\mathrm{Ca}^{2+}$ and is a much smaller moiety than TBT, which brings only 1 positive charge. Finally, TBT was shown to reduce the blood osmolality of flounder Platichthys flesus (Hartl et al. 2000) and to lower intracellular pH (Gray et al. 1986). Our study shows that organotins, in addition to causing MI, interfered with both phagocytosis and LR. Since the cell communicates with its environment through the plasma membrane, alteration of its composition or structure might well result in disruption of crucial functions like phagocytosis, lysosomal retention or basic cellular maintenance.

Both organotins in both experiments modulated PA. When PA was measured microscopically, all DBT and TBT doses significantly reduced PA. The reduction was more severe in Expt 1, especially with TBT. In the DBTexposed groups, while no significant differences were found before Day 18 in Expt 1, higher doses resulted in PA reduction, in both experiments. These results are in accordance with other studies using microscopic evaluation of PA of cells under chemical stress (Fries \& Tripp 1980, Cheng 1988a, Grundy et al. 1996). In contrast, when PA was measured spectrophotometrically, organotins produced a significant increase in phagocytosis. Although these results appear contradictory, the difference likely resides in the techniques used. Microscopic observations focused mainly on very active mature granulocytes and did not detect small and weak phagocytes like hyalinocytes. However, spectrophotometric measurements included all types of phagocytes and thus yielded a measure of the total PA of the mussels. Our results strongly suggest that the cumulative response of the phagocytic hemocytes was stimulated by organotins while the number of very active cells was reduced, which is consistent with both types of measurements. Such differences in the response of PA using those 2 techniques were also reported in the literature: when measured microscopically, $1 \mu \mathrm{g} \mathrm{l}^{-1} \mathrm{Cu}^{2+}$ inhibited PA (Cheng 1988b) whereas $5 \mathrm{\mu g} \mathrm{l}^{-1} \mathrm{Cu}^{2+}$ (Cheng \& Sullivan 1984) or $0.2 \mu \mathrm{g} \mathrm{l}^{-1} \mathrm{Cu}^{2+}$ (Pipe et al. 1999) enhanced PA when measured spectrophotometrically. Clearly, more spectrophotometric studies are needed to investigate the PA response of different hemocyte populations to environmental toxicants.

Phagocytosis is a complex process and could possibly be modulated by several mechanisms. Recently, 
cytokines (Il-1 $\alpha$, Il-2 and TNF- $\alpha$ ) and pro-opiomelanocortin (POMC)-derived peptides such as ACTH, $\beta$-endorphin and $\alpha$-MSH were shown to be present in molluskan hemocytes (Ottaviani et al. 1997a). In addition, these molecules were also shown to increase PA in mollusks (Ottaviani et al. 1995, 1997b). Since these molecules are known to be involved in stress response, it is possible that butyltins promoted their release and stimulated the hyalinocytes, although this remains to be demonstrated.

Several mechanisms may be involved in butyltinrelated inhibition of phagocytosis. According to Cheng (1983) and Renwrantz (1990), the phagocytic process can be subdivided into 4 steps: chemotaxis, recognition, internalization and intracellular degradation. Phagocytosis is, therefore, fundamentally dependent on membrane communication, for chemotaxis, fluidity of movement and internalization, as well as maintenance of internal ionic balance for the biochemical degradation. PA could have been disrupted through an impediment of cellular movement. While both butyltins can promote shape transformation by the disruption of the proton pump (Akhtar et al. 1987), TBT has a stronger affinity for the anion exchanger and could have interfered more with the integrity of the membrane than DBT. On the other hand, DBT could have interfered more than TBT with the locomotion of the cell via DBT's greater affinity for the plasma membrane-associated or cytoskeleton-associated sulfide groups (Ambrosini et al. 1996). Since cellular locomotion and attachment to substrates (including other cells) are controlled by proteins that join the underlying cytoskeleton to the plasma membrane (Stryer 1988), disruption of the sulfide groups would modify membrane fluidity and, thus, interfere with cellular locomotion. In addition, cell spreading, necessary to cellular locomotion, requires hemocytes to be isoosmotic or slightly hyperosomotic (Fisher 1986). By reducing the osmolalities, TBT could have inhibited cell spreading, promoting cell rounding and therefore reducing PA of larger and older cells but not smaller ones.

Finally, organotins could disrupt PA through disruption of the calcium pumps. Chemotaxis is dependent upon membrane receptors (lectins) (Mullainadhan \& Renwrantz 1986) while trans-membrane movements are facilitated by annexins (Creutz 1992). Both processes are $\mathrm{Ca}^{2+}$-dependent and situated predominantly on the polar surface of the membrane. DBT, having a greater affinity than TBT for the polar side of membranes and, possibly, being a better competitor for $\mathrm{Ca}^{2+}$, would have more of an impact on those processes than TBT. On the other hand, cellular locomotion is also closely associated with the cytoskeleton, which is anchored to the membrane through the anion exchanger, which is more susceptible to TBT than DBT. It is therefore possible that both TBT and DBT interfere with phagocytosis, in different ways or levels.

In Expt 1, the DBT-exposed groups retained more neutral red dye, on average, than the control groups. By Day 18, however, the trend reversed. Similarly, in Expt 2, the exposed groups showed an increase in neutral red retention, with the greatest difference from the controls on Day 6, followed by a decreasing difference in retention to the end of the experiment. In Expt 2, the incubation time did not appear to significantly change the degree of retention of the dye, however, the changes in methods used did reduce variability. Recently, Viarengo et al. (2000) reported the effects of some heavy metals $(\mathrm{Hg}, \mathrm{Cd}$ and $\mathrm{Cu}$ ) on the lysosomes of mussel hemocytes using a neutral red retention technique by microscopy with short incubation times ranging from 15 to $60 \mathrm{~min}$. This technique provided clear responses from lysosomes, but metal concentrations used where 1000 to 10000 times higher than those used in present experiments with TBT and DBT. The optimal response time is most probably a function of the concentrations of toxicants and seawater temperature, but this aspect of the lysosomal mechanism deserves further research.

The pattern of elevation in dye retention, followed by a decrease, may be due to the intrinsic ability of lysosomes to concentrate a wide range of contaminants including lipophilic xenobiotics (Moore 1990). Winston et al. (1996) reported that, under persistent xenobiotic challenge, oxidant stress can exceed normal antioxidant defenses and lead to release of hydrolytic enzymes into the cytosol. When the capacity to store butyltins is exceeded, the lysosomal membrane destabilizes, changing its permeability characteristics, and hydrolases are released into the cytoplasm (Anderson 1993). In the present study, we suggest that, after an initial increase in permeability, the lysosomes became overloaded, antioxidant protection was impaired and damage resulted. This would agree with other studies where xenobiotics were found to cause loss of lysosomal membrane integrity (Nott \& Moore 1987, Grundy et al. 1996), but using much higher concentrations of toxicants. According to Gundy et al. (1996), hemocytes exposed in vitro to $8.3 \mu \mathrm{g} \mathrm{l}^{-1}$ anthracene showed an augmentation of lysosome permeability (more dye retained) while exposure to anthracene at $50 \mathrm{\mu g} \mathrm{l}^{-1}$ in vitro or $14 \mathrm{~d}$ exposure to $250 \mathrm{ng} \mathrm{l}^{-1}$ in vivo showed a decrease in membrane integrity (less dye retained) indicative of leakage. In addition, Moore \& Farrar (1985) reported that mussels exposed to concentrations of 0 to $200 \mathrm{\mu g}^{-1}$ anthracene showed a linear decrease in LR while an exposure to 0 to $200 \mu \mathrm{g} \mathrm{l}^{-1}$ phenanthrene showed a sigmoidal relationship. These authors suggested that a critical concentration for a given compound is required for lysosome membrane damage. 
Furthermore, DBT could have enhanced pinocytosis, which could have resulted in an augmentation of the membrane permeability, as reflected by the fact that the DBT-exposed groups retained more neutral red dye than TBT and the control in Expt 1. These results are in agreement with earlier in vitro studies on mussel hemocytes (É. Pelletier \& I. Taupeau unpubl. data) showing that neutral red entered cells previously exposed to DBT more rapidly and in a greater volume than TBT-exposed groups.

Changes in immune parameters measured in this study were also reflected in the HC. For both experiments, a small increase was observed in $\mathrm{HC}$ in mussels exposed to either butyltin, but especially high doses of DBT early in the experiment. According to Pipe \& Coles (1995), the most commonly observed change in total $\mathrm{HC}$ following laboratory exposure of bivalves to toxicants is an increase in the number of cells. A number of studies reported such elevation in $\mathrm{HC}$ for bivalves under numerous conditions (Anderson 1981, Cheng 1988b, Renwrantz 1990, Auffret \& Oubella, 1994, Pipe \& Coles 1995, Coles et al. 1994, 1995). In addition, our results showed the pooled samples to present a greater variability than the non-pooled samples. This could be a result of the allogenic interaction postulated above, although as for the MI, this remains to be demonstrated.

Listonella anguillarum clearance was impeded by both butyltins following both experiments, and the effects were greater in juveniles than adults. Although Vibrio are not normally considered to be pathogens of adult bivalves, they are a good model for pathogenic bacterial clearance. Relationships between enhanced severity and incidence of disease and the presence of toxicants in fish are well known (Sinderman 1993), but a similar relationship in bivalves is only starting to emerge (Anderson 1981, Chu \& Hale 1994, Pipe \& Coles 1995, Fisher et al. 1995, Anderson et al. 1996, 1998). Anderson (1981) reported that the majority of clams Mercenaria mercenaria exposed to $200 \mathrm{ng} \mathrm{l}^{-1}$ benzo[a]pyrene, hexachlorobenzene or pentachlorophenol showed an impaired ability or even failure to clear injected Flavobacterium sp., while untreated clams cleared $>90 \%$. This author also showed that resistance to bacterial infection was decreased by exposure to xenobiotics and was directly proportional to tissue levels of the test pollutants. Winstead \& Couch (1988) showed that, after sublethal exposure to $n$-nitrosodiethylamine, the oyster Crassostrea virginica developed heavy infections of the protistan pathogen Perkinsus marinus, and the virulence of $P$. marinus was enhanced by exposure to TBT (Fisher et al. 1995, Anderson et al. 1996) and water-soluble fractions of PAH-contaminated sediments (Chu \& Hale 1994). Pipe \& Coles (1995) determined that a $7 \mathrm{~d}$ pre-exposure to
$<0.5 \mathrm{ng} \mathrm{l}^{-1}$ waterborne copper impaired the immune function of adult Mytilus edulis so that when challenged with the pathogenic bacterium Vibrio tubiashi, mortality rate increased. These authors suggested that pre-exposure of mussels to contaminants can influence the immune response when challenged with a potential pathogen, and can increase the pathogenicity of normally benign opportunistic strains (Pipe \& Coles 1995).

To date, 3 factors have been identified in the ability of bivalves to fight infection. First, lectins (agglutinins) react with bacteria and stimulate phagocytosis uptake (Olafsen 1986, Anderson et al. 1996) by facilitating bacterial aggregation or binding of bacteria to hemocytes (Renwratz \& Stahmer 1983). Secondly, lysosomal enzymes, which when released may act on the surface of bacteria and promote their recognition or destruction (Anderson et al. 1996). Finally, reactive oxygen intermediates (ROI) are generated with the respiratory burst associated with PA (Anderson 1996). Which, if any, of these defense mechanisms is impaired by the butyltins remains to be investigated.

Our short-term exposure to environmentally realistic butyltin concentrations associated with the use of a novel bacterial clearance test showed a clear relationship between immunomodulations of the internal defense of the mussels and an impairment in clearing Vibrio from their hemolymph. Therefore, chronic exposure of mussels to butyltins may alter their capability in terms of immune response to an opportunistic pathogen or exacerbate an existing infection, with obvious population consequences. In that respect, further work is needed to verify if a correlation exists between butyltin-contaminated sites and higher disease incidence.

In conclusion, this study showed that both butyltins affect each immunological end-point measured at most doses tested. In fact, impairment of cell function was observed at levels well below the accumulation threshold of the mussels for this study. In addition, this study showed DBT to modulate the internal defense of mussels at similar concentrations and, it appears, in different ways from TBT. These observations raise the following questions: Since DBT is a degradation product of TBT, are animals subjected to the damage inflicted from TBT and then from the by-product DBT? Are their inherent toxicities additive or synergistic? This study established strong and sustained responses of hemocyte functions of blue mussels exposed to environmentally relevant waterborne concentrations of TBT and DBT (0.04 to $0.67 \mathrm{nM}$ as $\mathrm{Sn}$ ), which is interpreted as an increase of their vulnerability to other environmental stressors and pathogens. In addition, what are the lowest TBT or DBT concentrations that could trigger the hemocyte functions of blue mussels under in vivo laboratory conditions similar to those described in the pre- 
sent work? That question was addressed by our laboratory and results are discussed in a LOEL study (St-Jean et al. 2002). There is no doubt that results obtained in controlled experiments are capable of establishing relationships between xenobiotics, immunomodulations and disease susceptibility. The results obtained in such experiments could eventually contribute greatly to a better understanding of field observations and ultimately facilitate biomonitoring and environmental assessment of locations potentially exposed to very low concentrations of butyltins.

Acknowledgements. The authors thank Mr. Ghislain Canuel for his excellent technical assistance and suggestions, Dr. Christian Belanger for his generous advice with the bacterial challenge and Susan Heaney from UPEI for providing the bacterial strain. Also, special thanks to Mr. Joe Caissie of NB for his mussels. This work was funded through a NSERC doctoral scholarship and a New Brunswick doctoral scholarship to S.D.S.J., through the Environmental Sciences Strategic Research Fund of the Department of Fisheries and Oceans Canada to S.C.C., as well as an NSERC operating grant to E.P.

\section{LITERATURE CITED}

Abd-Allah MAA (1995) Occurrence of organotin compounds in water and biota from Alexandria harbour. Chemo sphere 30:707-715

Akhtar AA, Upreti RK, Kidwai AM (1987) Interaction of diand tributyltin chloride with human erythrocyte membrane. Toxicol Lett 38:13-18

Alzieu C, Héral M, Thibaud Y, Dardignac MJ, Feuillet M (1981) Influence des peintures antisalissures à base d'orgaonstanniques sur la calcification de la coquille de l'huître Crassostrea gigas. Rev Trav Inst Pech Marit 45: 101-116

Ambrosini A, Bertoli E, Zolese G (1996) Effect of organotin compounds on membrane lipids: fluorescence spectroscopy studies. Appl Organomet Chem 10:53-59

Anderson DP (1990) Immunological indicators: effects of environmental stress on immune protection and disease outbreak. Amer Fish Soc Symp 8:38-50

Anderson RS (1981) Effects of carcinogenic and non-carcinogenic environmental pollutants on immunological functions in marine invertebrates. In: Dawe CJ, Harshbarger JC, Kondo S, Sagimura T, Takayama S (eds) Phylogenetic approach to cancer. Jpn Sci Soc Press, Tokyo, p 319-331

Anderson RS (1993) Modulation of nonspecific immunity by environmental stressors. In: Couch JA, Fournie JW (eds) Advances in fisheries science, pathobiology of marine and estuarine organisms. CRC Press, Boca Raton, FL, p 483-510

Anderson RS (1996) Production of reactive oxygen intermediates by invertebrate hemocytes: immunological significance. In: Söderhäll K, Vasta G, Iwanaga S (eds) New directions in invertebrate immunology. SOS Publications, Fair Haven, CT, p 109-129

Anderson RS, Unger MA, Burreson EM (1996) Enhancement of Perkinsus marinus disease progression in TBT-exposed oysters (Crassostrea virginica). Mar Environ Res 42:177-180

Anderson RS, Brubacher LL, Ragone Ccalvo L, Unger MA, Burreson EM (1998) Effect of tributyltin and hypoxia on the progression of Perkinsus marinus infections and host defense mechanisms in Crassostrea virginica (Gmelin). J Fish Dis 21:317-379

Auffret M, Oubella R (1994) Cytometric parameters of bivalve molluscs: effect of environmental factors. In: Stolen JS, Fletcher TC (eds) Modulators of fish immune responses, Vol 1. SOS Publications, Fair Haven, CT, p 23-32

Auffret M, Oubella R (1997) Hemocyte aggregation in the oyster Crassostrea gigas: in vitro measurement and experimental modulation by xenobiotics. Comp Biochem Physiol 118:705-712

Beaumont AR, Budd MD (1984) High mortality of the larvae of the common mussel at low concentrations of tributyltin. Mar Pollut Bull 15:402-405

Bouchard N, Pelletier É, Fournier M (1999) Effects of butyltin compounds on phagocytic activity of haemocytes from three marine bivalves. Environ Toxicol Chem 18:519-522

Boyer IJ (1989) Toxicity of dibutyltin, tributyltin and other organotin compounds to humans and to experimental animals. Toxicology 55:253-298

Bryan GW, Gibbs PE, Burt GR, Hummerstone LG (1987) The effects of tributyltin (TBT) accumulation on adult dogwhelks, Nucella lapillus: long-term field and laboratory exposures. J Mar Biol Assoc UK 67:525-544

Cheng TC (1983) The role of lysosomes in molluscan inflammation. Am Zool 23:129-144

Cheng TC (1988a) In vivo effects of heavy metals on cellular defense mechanisms of Crassostrea virginica: phagocytic and endocytotic indices. J Invertebr Pathol 51:215-220

Cheng TC (1988b) In vivo effects of heavy metals on cellular defense mechanisms of Crassostrea virginica: total and differential haemocyte counts. J Invertebr Pathol 51: 207-214

Cheng TC, Sullivan JT (1984) Effects of heavy metals on phagocytosis by molluscan hemocytes. Mar Environ Res 14:305-315

Chu FLE, Hale RC (1994) Relationship between pollution and susceptibility to infectious disease in the Eastern oyster, Crassostrea virginica. Mar Environ Res 38:243-256

Cima F, Ballarin L, Bressa G, Burighel P (1998) Cytoskeleton alterations by tributyltin (TBT) in tunicate phagocytes. Ecotoxicol Environ Saf 40:160-165

Coles JA, Farley SR, Pipe RK (1994) Effects of fluoranthene on the immunocompetence of the common marine mussel, Mytilus edulis. Aquat Toxicol 30:367-379

Coles JA, Farley SR, Pipe RK (1995) Alteration of the immune response of the common marine mussel Mytilus edulis resulting from exposure to cadmium. Dis Aquat Org 22: $59-65$

Creutz CE (1992) The annexins and exocytosis. Science 258: 924-931

Dyrynda EA, Pipe RK, Burt GR, Ratcliffe NA (1998) Modulations in the immune defenses of the mussels (Mytilus edulis) from contaminated sites in the UK. Aquat Toxicol 42:169-185

Elston R (1984) Prevention and management of infectious diseases in intensive mollusc husbandry. J World Mar Soc 15: 284-300

Ey PL, Jenkin CR (1982) Molecular basis of self/non-self discrimination in the invertebra. In: Cohen N, Sigal MM (eds) Phylogeny and ontogeny of the reticuloendothelial system, Vol 3. Plenum Publishing, New York, p 321-391

Fent K (1996) Ecotoxicology of organotin compounds. Crit Rev Toxicol 26:1-117

Fent K, Hunn J (1995) Organotins in freshwater harbors and rivers: temporal distribution, annual trends and fate. Environ Toxicol Chem 14:1123-1132

Fisher WS (1986) Structure and functions of oyster hemocytes. 
In: Brehélin M (ed) Immunity in invertebrates. SpringerVerlag, Berlin, p 25-35

Fisher WS, Wishkovsky A, Chu FL (1990) Effects of tributyltin on defense-related activities of oyster hemocytes. Arch Environ Toxicol 19:354-360

Fisher WS, Olivier LM, Sutton EB, Manning CS, Walker WW (1995) Exposure of Eastern oysters to tributyltin increases the severity of Perkinsus marinus disease. J Shell Res 14: 265-266

Fries CR, Tripp MR (1980) Depression of phagocytosis in Mercenaria mercenaria following chemical stress. Dev Comp Immunol 4:233-244

Gray BH, Porvaznik M, Flemming C, Lanfong HL (1986) Trin-butyltin aggregates and membrane cytotoxicity in human erythrocytes. Lab Invest 54:1234-1239

Gray BH, Porvaznik M, Flemming C, Lanfong HL (1987) Trin-butyltin: a membrane toxicant. Toxicology 47:35-54

Grundy MM, Moore MN, Howell SM, Ratcliffe NA (1996) Phagocytic reduction and effects on lysosomal membranes by polycyclic aromatic hydrocarbons, in haemocytes of Mytilus edulis. Aquat Toxicol 34:273-290

Hartl MG, Hutchinson S, Hawkins LE (2000) Reduced blood osmolality in freswater-adapted o-group flounder, Platichtys flesus (L.), exposed to environmental levels of sediment-associated tributyl- and triphenytin. Mar Pollut Bull 40:792-794

Jeffries V (1983) Three Vibrio strains pathogenic to larvae of Crassostrea gigas and Ostrea edulis. Aquaculture 29: 210-207

Kure LK, Depledge MH (1994) Accumulation of organotin in Littorina littorea and Mya arenaria from Danish coastal waters. Environ Pollut 84:149-157

Lambert C, Nicholas JL (1998) Specific inhibition of chemiluminescent activity by pathogenic Vibrio in hemocytes of two marine bivalves: Pecten maximus and Crassostrea gigas. J Invertebr Pathol 71:53-63

Lane L, Birkbeck TH (1999) Toxicity of bacteria towards haemocytes of Mytilus edulis. Aquat Living Resour 12: 343-350

Lowe DM, Pipe RK (1994) Contaminant induced lysosomal membrane damage in marine mussel digestive cells: an in vitro study. Aquat Toxicol 30:357-365

McHenery JG, Birkbeck TH (1986) Inhibition of filtration in Mytilus edulis L. by marine vibrios. J Fish Dis 9:249-256

Michel P, Averty B (1999) Contamination of French coastal waters by organotins compounds: 1997 update. Mar Pollut Bull 38:268-275

Moore MN (1990) Lysosomal cytochemistry in marine environmental monitoring. Histochem J 22:187-191

Moore MN, Farrar SV (1985) Effects of polynuclear aromatic hydrocarbons on lysosomal membranes in mollusks. Mar Environ Res 17:222-225

Mullainadhan P, Renwrantz L (1986) Lectin-dependant recognition of foreign cells by hemocytes of the mussel, Mytilus edulis. Immunobiology 171:263-273

Nott JA, Moore MN (1987) Effects of polycyclic aromatic hydrocarbons on molluscan lysosomes and endoplasmic reticulum. Histochem J 19:357-368

Nottage AS, Birkbeck TH (1990) Interactions between different strains of Vivrio alginolyticus and hemolymph fractions from adult Mytilus edulis. J Invertebr Pathol 56: $15-19$

Olfasen JA (1986) Invertebrate lectins: biochemical heterogeneity as a possible key to their biological function. In: Brehélin $M$ (ed) Immunity in the invertebrates. SpringerVerlag Berlin, p 94-100

Ottaviani E, Franchini A, Cassanelli S, Genedani S (1995)
Cytokines and invertebrate immune responses. Biol Cell 85:87-91

Ottaviani E, Franchini A, Franceschi C (1997a) Pro-oipomelanocortin-derived peptides, cytokines, and nitric oxide in immune responses and stress: an evolutionary approach. Int Rev Cytol 170:79-141

Ottaviani E, Franchini A, Fontanili P (1997b) The effect of corticotropin-releasing factor and pro-opiomelanocortinderived peptides on the phagocytosis of molluscan hemocytes. Experientia 50:837-839

Oubella R (1997) Immunomodulation dans des populations de mollusques bivalves de la rade de Brest. Ann Inst Oceanogr 73:77-87

Page DS, Widdows J (1991) Temporal and spatial variation in levels of alkyltins in mussel tissues: a toxicological interpretation of field data. Mar Environ Res 32:113-129

Pipe RK, Coles JA (1995) Environmental contaminants influencing immune function in marine bivalve mollusks. Fish Shell Immunol 5:581-595

Pipe RK, Coles JA, Farley SR (1995) Assays for measuring immune response in the mussel Mytilus edulis. In: Stolen JS, Fletcher TC, Smith SA, Zelikoff JT, Kaattari SL, Anderson RS, Soderhall K, Weeks-Perkins BA (eds) Techniques in fish immunology, Vol 4. Immunology and pathology of aquatic invertebrates. SOS Publications, Fair Haven, CT, p 93-100

Pipe RK, Coles JA, Carissan FMM, Ramanathan K (1999) Copper induced immunomodulation in the marine mussel, Mytilus edulis. Aquat Toxicol 46:43-54

Porvaznik M, Gray BH, Mattie D, Jackson AG, Omlor RE (1986) The ultrastructural localization of tri- $n$-butyltin in human erythrocyte membranes during shape transformation leading to hemolysis. Lab Invest 54:254-267

Renwrantz L (1990) Internal defense system of Mytilus edulis. In: Stefano GB (ed) Studies in neuroscience, neurobiology of Mytilus edulis. Manchester University Press, Manchester, p 256-275

Renwrantz L, Stahmer A (1983) Opsonizing properties of an isolated hemolymph agglutinin and demonstration of lectin-like recognition molecules at the surfaces of hemocytes from Mytilus edulis. J Comp Physiol 149:535-546

Saboori AM, Newcombe DS (1992) Environmental chemicals with immunotoxic properties. In: Newcombe DS, Rose NR, Bloom JC (eds) Clinical immunotoxicology. Raven Press, New York, p 365-400

Sinderman CJ (1993) Interactions of pollutants and disease in marine fish and shellfish. In: Couch JA, Fournie JW (eds) Advances in fisheries science: pathology of marine and estuarine organisms. CRC Press, Boca Raton, FL, p 451-482

St-Jean SD, Courtenay SC, Pelletier É (1999) Butyltin concentrations in sediments and blue mussels (Mytilus edulis) of the southern Gulf of St. Lawence, Canada. Environ Technol 20:181-189

St-Jean SD, Pelletier É, Courtenay SC (2002) Very low levels of waterborne butyltins modulate hemocyte functions in the blue mussel Mytilus edulis. Mar Ecol Prog Ser 236: 155-161

St-Louis R, Gobeil C, Pelletier É (1997) Tributyltin and its degradation products in the St. Lawrence Estuary. Environ Technol 18:1209-1216

Stryer L (1988) Biochemistry, 3rd edn. WH Freeman, New York

Viarengo A, Marro A, Marchi B, Burlando B (2000) Single and combined effects of heavy metals and hormoses on lysosomes of haemolymph cells from the mussel Mytilus galloprovincialis. Mar Biol 137:907-912 
Waite ME, Waldock MJ, Thain JE, Smith DJ, Milton SM (1991) Reduction in TBT concentrations in UK estuaries following legislation in 1986 and 1987. Mar Environ Res 32:89-111

Winstead JT, Couch JA (1988) Enhancement of protozoan pathogen Perkinsus marinus infections on American oysters Crassostrea virginica exposed to the chemical carcinogen n-nitrosodiethylamine (DENA). Dis Aquat Org 5: 205-213

Editorial responsibility: Otto Kinne (Editor),

Oldendorf/Luhe, Germany
Winston GW, Moore MN, Kirchin MA, Soverchia C (1996) Production of reactive oxygen species by hemocytes from the marine mussel, Mytilus edulis: lysosomal localization and effect of xenobiotics. Comp Biochem Physiol 113:221-229

Zucker RM, Elstein KH, Easterling RE, Ting-Beall HP, Allis JW, Massaro JE (1988) Effects of tributyltin on biomembranes: alteration of flow cytometric parameters and inhibition of $\mathrm{Na}^{+}, \mathrm{K}^{+}$-ATPase two-dimensional crystallization. Toxicol Appl Pharmacol 96:393-403

Submitted: May 28, 2001; Accepted: December 6, 2001

Proofs received from author(s): May 21, 2002 